\title{
Attitudes of young consumers at college age towards the purchase of unpackaged goods in the context of the world economy - a case study Czech Republic
}

\author{
Miroslava Navrátilová ${ }^{1, *}$, David Brož ${ }^{1}$, and Markéta Beranová ${ }^{1}$ \\ ${ }^{1}$ Czech University of Life Sciences in Prague, Faculty of Economics and Management, Department \\ of Economics, Kamýcká 129, Prague, 165 21, Czech Republic
}

\begin{abstract}
Research background: Today, society faces many challenges such as biodiversity loss, water and soil pollution, deforestation and unsustainable production. Responsible waste production and waste management can be instrumental in improving the overall sustainability of the planet. Thus, unpackaged goods are one of the tools available, especially for the young generation, which can be used. The use of the circular economy will be a necessity to maintain a high standard of living especially for the current college age generation.

Purpose of the article: The main purpose of this paper is to find out the attitude and opinion of the college age generation towards unpackaged goods, zero waste and general awareness of waste and environment. Unpackaged food is becoming, more and more a sought after standard and especially for young people. Unfortunately, the current COVID 19 crisis has significantly affected alternative ways of selling, led by the concept of unpackaged food.

Methods: The contingency tables and $\chi^{2}$ test was used.

Findings \& Value added: The results show more than $83 \%$ of respondents sort waste, with plastics, paper and glass being the most frequently sorted waste. Awareness of the concept of Zero Waste was declared by $90.7 \%$ of college age youth. Females demonstrated higher awareness of this issue than males $(93.3 \%$ vs. $84.1 \%)$. The concept of zero packaging in retail was noted by $85.3 \%$ of people. Respondents had encountered some forms of zero packaging sales.
\end{abstract}

Keywords: consumer; environment, globalization, unpacked good, waste

JEL Classification: A11; F06; F64; Q53

\footnotetext{
* Corresponding author: navratilovam@pef.czu.cz
} 


\section{Introduction}

There is a general understanding of the effects of climate change in contemporary global society, including loss of biodiversity, increased air, water and soil pollution, deforestation, and limited resources and materials due to overconsumption of unsustainable production processes (Nizar et al., 2018). One of the major global environmental problems is the increase in the amount of solid waste produced (Song et al., 2015). Rapid urbanization, industrialization, technological advancement, and population growth can be identified as the main causes of this condition (Sharma, 2019). After the year 2000, the world has witnessed a large increase in the price of natural resources and an increasing awareness of the limited availability of fossil fuels, mineral resources, and agricultural and forestry products (Kumar et al., 2021). The continuous depletion of natural finite resources means an uncertain future for our planet (Song et al., 2015). Thus, the increasing waste production poses a great challenge to humanity and conditions the need for finding new innovative and environmentally friendly technologies in waste management (Sharma, 2019). According to the World Bank estimates, it can be assumed that by 2050, 3.40 billion tons of waste will be produced annually worldwide, marking a high increase from the current value of approximately 2.01 billion tons Kaza et al. (2018). According to the International Monetary Fund, waste management expenditures currently account for about 0.5 percent of global GDP (Marti and Puertas, 2021).

There are significant differences in waste management across countries globally. Developing countries produce more than half of the world's solid waste, and their annual public expenditures on waste treatment, approximately $\$ 46$ billion, represent little more than one-tenth of the roughly $\$ 400$ billion spent on waste treatment worldwide (Marti a Puertas, 2021). Within the European Union, environmental protection and rational resource management are considered to be of particular importance in sustainable development (Zarebska et al., 2018).

At present, the world is dominated by a rather linear economic system (Nizar et al., 2018). Tantau et al. (2018) highlight the need to transform the traditional model of production, consumption and waste disposal and consider circular economy as one of the strategic issues in the efforts to achieve sustainable economic systems. The circular economy is a concept whose basic principle is the effort to promote the efficient use of resources and energy represented by waste materials through their reuse as secondary raw materials. In the Czech Republic, the public discussion on circular economy started in 2015 and focused mainly on waste management and recycling technologies (Kočí et al., 2016). Existing solid waste management schemes have been improved by implementing advanced systems for the recovery and reuse of different materials (Burlakovs et al., 2018).

Based on his research, Escursell (2020)notes that many current studies on packaging issues in the context of the circular economy focus on business models and stakeholders, and considerable attention is also paid to existing packaging strategies for materials, logistics, and legislation and policies. Also Iqbal et al. (2020) consider the protection of natural resources, reduction of waste and minimization of energy consumption as the primary objective of green supply chain management. In the retail sector, alternative forms of sales have come to the fore in recent years, including, among others, unpackaged sales, which were initially implemented mainly in specialised retail outlets (Beitzen-Heineke et al., 2017). In view of the growing consumer interest in healthy lifestyles and environmental issues, the trend towards zero-label sales has also been accepted in various forms by multinational companies and is becoming part of the conventional retail network. Alvarado et al. (2020) describe the initiatives of alternative agri-food networks as extremely resilient in times of crisis, which they document with the example of the current Covid 19 pandemic.

It can be concluded that the modern world can be characterised by high consumption in all areas of everyday life (Ramazanov et al., 2021). In this context, the importance of market 
segmentation and the need to understand the specific requirements of particular consumer groups come to the fore. Today's young people are the first global generation, thanks in particular to the impact of new communication technologies and increasing digitalisation at all levels. The views of today's younger generation will to some extent determine the future shape of the world, as its members enter the productive phase of their lives and will thus have considerable purchasing power. Noble et al. (2009) highlight the specifics of consumer behaviour and consumption preferences of university students within the young Generation Y. A similar position is taken by Generation $\mathrm{Z}$ based on their research on university students. Kamenidou et al. (2019).

The aim of the paper is to evaluate the attitude of young college-age consumers towards buying goods without packaging in the context of the environment and the ideas of the zero waste movement. The paper consists of several logically related parts. The Introduction section provides a theoretical insight into the issue at hand. In the Materials and methods chapter, the sample of respondents of the primary research conducted is characterized and a description of the methods used is made along with the null hypotheses established. This is followed by the Results and Discussion chapters, in which the results are elaborated and further discussed and compared with similar research. Finally, the paper concludes with a summary of

\section{Methods}

The theoretical framework of the presented article was prepared with the scientific and professional articles and supplemented with current information from relevant sources. It was a method of examining documents. Primary data were obtained by quantitative research using questionnaire survey methods. The research parameters were chosen with regard to Noble et al. (2009), who focused on consumer research at college age. The research was carried out in January 2021 through electronic surveys. From total number of respondents $(n=389)$, $27.5 \%$ (107) were men and $72.5 \%$ (282) were women. Due to the focus of the research, all participants in the questionnaire survey were students from some of the universities in the Czech Republic aged 19 to 26 years.

The contingency tables and $\chi^{2}$ test as methods were used for evaluation relationship between variables. The type of the contingency table depend on number of rows $r$ and the number of columns s, is means $r \times s$ (Hindls et al, 2018). Obviously, $\chi^{2}$ is a measurement of the overall dissimilarity of $n_{i j}$ and $m_{i j}$.

$$
\begin{gathered}
m_{i j}=\frac{n_{i} \cdot n_{j}}{n} \\
\chi^{2}=\sum \frac{(\text { frequency observed }- \text { frequency expected })^{2}}{\text { frequency expected }} \\
\chi^{2}=\sum_{i=1}^{r} \sum_{j=1}^{s}\left(n_{i j}-m_{i j}\right)^{2} / m_{i j}
\end{gathered}
$$

$i$ and $j$ are indexes of rows and columns, $n_{i j}$ are observed marginal frequencies, $n_{i}$ and $n_{j}$ are marginal totals, $n$ is grand total of observations, $m_{i j}$ are expected frequencies. We compare $\chi^{2}$ to the critical value $\chi^{2}$ with a chi-square distribution of $(r-1)(s-1)$ degrees of freedom at the chosen level of significance. We reject the hypothesis if $\chi^{2}$ is larger than the table value. This test is valid asymptotically, and thus can only be applied if there is a sufficient number of observations. All expected values ought to be higher than one (Hendl, 2009); at the same time, the table should not contain more than $20 \%$ theoretical incidence rates (frequencies) of 
less than 5.Where zero values occur in any of the fields, we proceed to analyze a derived table, created by merging a small number of categories (Hendl, 2012). Cramer's v was used for the strength of the relationship.

Table 1. Null Hypothesis

\begin{tabular}{|c|c|}
\hline $\begin{array}{c}\text { No. of } \\
\text { Hypothesis }\end{array}$ & Text of Hypothesis \\
\hline H01 & $\begin{array}{l}\begin{array}{l}\text { The respondent's interest in the environment does not depend on their } \\
\text { gender. }\end{array}\end{array}$ \\
\hline H02 & $\begin{array}{l}\text { Knowledge of zero waste does not depend on the gender of the } \\
\text { respondent. }\end{array}$ \\
\hline
\end{tabular}

Source: own research (2021)

\section{Results and Discussion}

Environmental issues can now be considered one of the fundamental global problems of our planet. In this context, the general interest of university students in the environment was examined. The results show that the respondents declared a high level of interest, at almost $97.0 \%(96.9 \%, 377)$. Of the total number of participants $(n=389), 65.6 \%(255)$ expressed a definite interest, and almost one-third $(31.4 \%, 122)$ of the respondents identified with the answer "rather yes". Research of Naderi and van Steenburg (2018) attributes proenvironmental behaviour in young people to rational and person-centred reasons. Furthermore, differences in attitudes between men and women were explored in more detail in this question (see null hypothesis H01). The findings are presented in the following table (Table 2.).

Table 2. Respondent's interest in the environment in relation to respondent's gender

\begin{tabular}{|c|c|c|c|c|}
\hline $\begin{array}{c}\text { Gender of } \\
\text { respondent }\end{array}$ & Absolutely yes & Rather yes & Rather no & Total \\
\hline Female & 193 & 88 & 1 & 282 \\
\hline Male & 62 & 34 & 11 & 107 \\
\hline Total & 255 & 122 & 12 & 389 \\
\hline \multicolumn{5}{|c|}{ Relative frequencies within gender of respondents } \\
\hline Female & $68,4 \%$ & $31,2 \%$ & $0,4 \%$ & $100.0 \%$ \\
\hline Male & $57,9 \%$ & $31,8 \%$ & $10,3 \%$ & $100.0 \%$ \\
\hline Total & $65,6 \%$ & $31,4 \%$ & $3,1 \%$ & $100.0 \%$ \\
\hline \multicolumn{5}{|c|}{ Adjusted residues } \\
\hline Female & 8,1 & $-0,4$ & $-7,7$ & \\
\hline Male & $-8,1$ & 0,4 & 7,7 & \\
\hline
\end{tabular}

Source: own research (2021)

The calculated $\chi 2$ statistic for Table 2 , of 26.08 , is higher than the critical value of the $\chi 2$ distribution by 2 degrees of freedom at the 0.05 significance level. Therefore, the null hypothesis can be rejected. The degree of dependence as measured by Cramer's V is 0.26 , the dependence is moderate. Thus, higher interest in environmental issues is shown by female university students who expressed $99.6 \%$ interest in environmental issues. Of the total number of female participants $(\mathrm{n}=282), 68.4 \%(193)$ chose the answer "definitely yes" and more than one-third indicated the answer "rather yes" $(31.2 \%, 88)$. 
Waste management and waste recovery are often debated topics in today's global society. Waste management is very closely linked to the issue of packaging and the overuse of packaging in commerce. It is packaging that is a significant source of municipal waste in particular. For these reasons, it was first examined how respondents sort waste in their households. Of the total number of participants $(n=389)$, the vast majority of respondents reported that they separate waste in their households, $83.0 \%$ (323 people). In terms of the individual components collected separately, the most common are plastic $(98.1 \%, 317)$, paper $(91.6 \%, 296)$ and glass $(90.7 \%, 291)$. Furthermore, university students reported that they sort beverage cartons $(40.9 \%, 132)$, metal waste $(31.3 \%, 101)$ and bio-waste $(22.0 \%, 71)$. Respondents most frequently cited lack of space in the home $(51.5 \%, 34)$ and the absence of containers for sorted waste at home $(33.3 \%, 22)$ as reasons for not sorting waste $(66,17.0 \%$ of total $\mathrm{n}=389)$. More than $90.0 \%(91.3 \%, 355)$ of respondents expressed the opinion that there had been an increase in waste generation in their households in the last year, which was mainly attributed to changes in their personal and professional lives resulting from the Covid19 pandemic.

Currently, the concept of "zero waste" is becoming more relevant through the reduction of waste disposal (Burlakovs et al., 2018). Fulfilling this rule should be achieved through conscious behaviour and informed choice (Song et al., 2015). For this reason, it was further investigated whether university students are familiar with the concept of zero waste. Approximately nine tenths of the respondents answered positively to this question $(90.7 \%$, 353 persons). Out of the total number of participants $(n=389), 36.2 \%(141)$ of the respondents declared exact knowledge of the concept and more than half $(54.5 \%, 212)$ answered that they knew partly what it was. The null hypothesis $\mathrm{H} 02$ was further tested for this question. The results are presented in Table 3.

Table 3. Knowledge of zero waste in relation to the gender of the respondent

\begin{tabular}{|c|c|c|c|c|}
\hline $\begin{array}{c}\text { Gender of } \\
\text { respondent }\end{array}$ & $\begin{array}{c}\text { Yes, I know the } \\
\text { exact content of } \\
\text { the definition }\end{array}$ & $\begin{array}{c}\text { Yes, I know partly } \\
\text { what it is }\end{array}$ & $\begin{array}{c}\text { No I never heard } \\
\text { about this } \\
\text { definition }\end{array}$ & Total \\
\hline Female & 108 & 155 & 19 & 282 \\
\hline Male & 33 & 57 & 17 & 107 \\
\hline Total & 141 & 212 & 36 & 389 \\
\hline \multicolumn{5}{|c|}{ Relative frequencies within gender of respondents } \\
\hline Female & $38.3 \%$ & $55.0 \%$ & $6.7 \%$ & $100.0 \%$ \\
\hline Male & $30.8 \%$ & $53.3 \%$ & $15.9 \%$ & $100.0 \%$ \\
\hline Total & $36.2 \%$ & $54.5 \%$ & $9.3 \%$ & $100.0 \%$ \\
\hline \multicolumn{5}{|l|}{ Adjusted residues } \\
\hline Female & 5.8 & 1.3 & -7.1 \\
\hline Male & -5.8 & -1.3 & 7.1 \\
\hline
\end{tabular}

Source: own research (2021)

The calculated $\chi^{2}$ statistic for Table 3 of 8.25 is higher than the critical value of the $\chi^{2}$ distribution by 2 degrees of freedom at the 0.05 significance level. Therefore, the null hypothesis can be rejected. The degree of dependence as measured by Cramer's V is 0.15 ; the dependence is weak. Women showed higher general knowledge of the concept of zero waste compared to men (93.3\% vs. 84.1\%). Differences can also be observed for individual responses, where less than $40.0 \%(38.3 \%, 108)$ of the total number of female respondents $(\mathrm{n}$ = 282) declared accurate knowledge of the concept. Badowska and Delińska (2019) concluded in their research, conducted among young respondents under 24 years of age in 
Poland, that only one third of respondents $(32.02 \%)$ showed knowledge of zero waste. The popularization of the concept and ideas of zero waste has been happening especially in recent years, which may have influenced the results of this research, as Badowska and Delińska (2019) conducted their survey in the period 2017-2018.

Jerzyk (2016), based on his research, declares clear differences between the perception of packaging between different generations of consumers. While millennials mainly look at packaging for its aesthetics, innovativeness and environmental friendliness, Generation $\mathrm{Z}$ considers the originality and prestige of the packaging and the possibility to express their belonging to a certain social group with their purchase to be important. Similar conclusions to those expressed by Jerzyk (2016) about Generation Z were also reached by Noble et al. (2009) about Generation Y university students. It can therefore be assumed that this is the respondents' opinion in the context of age rather than a settled generational statement.

Majority of respondents, $85.3 \%$ (332) of the total number of young people of college age who participated in the survey $(n=389)$, had encountered the concept of zero packaging in retail. In terms of the different forms of purchase, young people most frequently noted specialised unpackaged stores $(63.8 \%, 248)$, followed by the possibility of buying unpackaged food from large online food portals with home delivery $(42.4 \%, 165)$ and also the possibility of such purchase in some supermarkets or hypermarkets $(32.4 \%, 126)$.

Approximately one-quarter of the respondents made a purchase without packaging $(24.9 \%$, 97). Only $6.9 \%$ (27) stated that they repeatedly purchase products without packaging. In the authors' opinion, this can be attributed to the fact that young people of college age generally have limited income and therefore limited financial resources. In terms of the barriers that respondents perceive to the results are consistent with the views of Marken and Hörisch (2019). In terms of responses, the respondents indicated that they do not have non-package stores near their residence. The other main problem was considered to be the limited range of products.

\section{Conclusion}

Waste as a product of contemporary civilization is one of the central problems of the world economy on a global scale. The issue of packaging material and its excessive use in all countries of the world, regardless of their economic development, is very much in line with this. In the context of current world events, the world public focuses its attention primarily on the subject of global health, but even today the importance of issues related to ecology and the environment cannot be ignored, either in economic or social terms. This paper deals with the attitude of young consumers - university students towards the purchase of unpackaged goods. The results presented were obtained through primary research involving 389 respondents aged 19-26 years. The research was conducted in January 2021 by an electronic survey in the Czech Republic. The results show more than $83 \%$ of respondents sort waste, with plastics, paper and glass being the most frequently sorted waste. Awareness of the concept of zero waste was declared by $90.7 \%$ of college age youth. Females demonstrated higher awareness of this issue than males $(93.3 \%$ vs. $84.1 \%)$. The concept of zero packaging in retail was noted by $85.3 \%$ of people. Respondents had encountered some forms of zero packaging sales. Regarding the purchase of unpackaged goods, most respondents reported that they had not purchased unpackaged products to date. Difficult access to specialist outlets and limited range of products were the main reasons.

\section{References}

1. Alvarado, M. A., Denis, P., Azzimonti, M., Vysokolan, L. C., \& Tcheton, S. (2020). Alternative Agri-Food Networks and Their Role in Re-Localization of Food and 
Creation of Shared Value: The Case of the Leuven Food Hub. Transdisciplinary Insights, 4(1), 182-208.

2. Badowska, S., \& Delińska, L. (2019). The zero waste concept from young consumers' perspective. Does gender matter? Annales Universitatis Mariae Curie-Skłodowska, sectio H-Oeconomia, 53(1), 7-17.

3. Beitzen-Heineke, E. F., Balta-Ozkan, N., \& Reefke, H. (2017). The prospects of zeropackaging grocery stores to improve the social and environmental impacts of the food supply chain. Journal of Cleaner Production, 140, 1528-1541.

4. Burlakovs, J., Jani, Y., Kriipsalu, M., Vincevica-Gaile, Z., Kaczala, F., Celma, G., Ozola, R., Rozina, L., Rudovica, V., Hogland, M., Viksna, A., Pehme, K. M., Hogland, W., \& Klavins, M. (2018). On the way to 'zero waste' management: Recovery potential of elements, including rare earth elements, from fine fraction of waste. Journal of Cleaner Production, 186, 81-90.

5. Escursell, S., Llorach-Massana, P., \& Roncero, M. B. (2021). Sustainability in ecommerce packaging: A review. Journal of Cleaner Production, 280.

6. Hendl, J. (2012). Přehled statistických metod: Analýza a metaanalýza dat (4., rozš. vyd.). Portál.

7. Hindls, R., Arltová, M., Hronová, S., Malá, I., Marek, L., Pecáková, I., \& Řezanková, H. (2018). Statistika v ekonomii. Professional Publishing.

8. Iqbal, M. W., Kang, Y., \& Jeon, H. W. (2020). Zero waste strategy for green supply chain management with minimization of energy consumption. Journal of Cleaner Production, 245.

9. Jerzyk, E. (2016). Design and Communication of Ecological Content on Sustainable Packaging in Young Consumers' Opinions. Journal of Food Products Marketing, 22(6), 707-716.

10. Kamenidou, I. C., Mamalis, S. A., Pavlidis, S., \& Bara, E. Z. G. (2019). Segmenting the Generation Z Cohort University Students Based on Sustainable Food Consumption Behavior: A Preliminary Study. Sustainability, 11(3), 837.

11. Kaza, S., Yao, L., Bhada-Tata, P., \& Van Woerden, F. (2018). What a Waste 2.0: A Global Snapshot of Solid Waste Management to 2050. International Bank for Reconstruction and Development / The World Bank. https://openknowledge.worldbank.org/handle/10986/30317

12. Kočí, V., Rocha, J. L., \& Zakuciová, K. (2016). The concept of Circular Economy applied to CCS, Waste and Wastewater Treatment Technologies. 5th Annual International Conference on Sustainable Energy and Environmental Sciences SEES 2016 (pp. 80-83).

13. Kumar, A., Adamopoulos, S., Jones, D., \& Amiandamhen, S. O. (2021). Forest Biomass Availability and Utilization Potential in Sweden: A Review. Waste and Biomass Valorization, 12(1), 65-80.

14. Marken, G. H., \& Hörisch, J. (2019). Purchasing unpackaged food products. Sustainability Management Forum | Nachhaltigkeits Management Forum, 27(3-4), 165 175.

15. Marti, L., \& Puertas, R. (2021). Influence of environmental policies on waste treatment. Waste Management, 126, 191-200.

16. Naderi, I., \& Van Steenburg, E. (2018). Me first, then the environment: young Millennials as green consumers. Young Consumers, 19(3), 280-295. 
17. Nizar, M., Munir, E., Munawar, E., \& Irvan, D. (2018). Implementation of zero waste concept in waste management of Banda Aceh City. Journal of Physics: Conference Series, 1116.

18. Noble, S. M., Haytko, D. L., \& Phillips, J. (2009). What drives college-age Generation Y consumers? Journal of Business Research, 62(6), 617-628.

19. Ramazanov, I. A., Panasenko, S. V., Cheglov, V. P., Krasil'nikova, E. A., \& Nikishin, A. F. (2021). Retail Transformation under the Influence of Digitalisation and Technology Development in the Context of Globalisation. Journal of Open Innovation: Technology, Market, and Complexity, 7(1), 47.

20. Sharma, K., \& Garg, V. K. (2019). Vermicomposting of Waste. Sustainable Resource Recovery and Zero Waste Approaches, 133-164.

21. Song, Q., Li, J., \& Zeng, X. (2015). Minimizing the increasing solid waste through zero waste strategy. Journal of Cleaner Production, 104, 199-210.

22. Tantau, A., Maassen, M., \& Fratila, L. (2018). Models for Analyzing the Dependencies between Indicators for a Circular Economy in the European Union. Sustainability, 10(7), 2141.

23. Zarębska, J., Żabińska, I., Cierna, H., \& Sujova, E. (2018). Assessment of the Changes in the Economy of Municipal Waste in Poland after 2004. New Trends in Production Engineering, 1(1), 55-61. 